\title{
Periode Kritis Jagung Manis Berkompetisi dengan Gulma Pada Entosil Lombok Tengah
}

\section{Critical Period of Sweet Corn Competing With Weeds In Central Lombok Entosyle}

\author{
I Ketut Ngawit*, M. Taufik Fauzi \\ Jurusan Budidaya Pertanian, Fakultas Pertanian, Universitas Mataram. \\ *Corresponding Author Email: ngawit@unram.ac.id
}

Manuscript received: 08-12-2020. Accepted: 25-10-2021

\begin{abstract}
ABSTRAK
Gulma tidak selalu merugikan tanaman, karena ada periode waktu kehadirannya paling berpengaruh terhadap pertumbuhan tanaman dan periode waktu itu disebut piriode kritis. Telah dilakukan penelitian yang bertujuan untuk menentukan periode kritis jagung manis berkompeisi dengan gulma pada entisol Lombok Tengah. Metode penelitian eksperimen dengan percobaan di lapang menggunakan Rancangan Acak Kelompok (RAK), yang terdiri dari 12 perlakuan, tanaman bebas gulma (TBG) sejak tanam sampai umur, 10;20;30; 40; 50 dan 60 hari dan tanaman dibiarkan bergulma (TG) sejak tanam sampai umur 10;20;30;40;50 dan 60 hari. Hasil penelitian menunjukkan bahwa keberadaan gulma yang dapat ditoleirir pada tanaman jagung manis hanya sampai umur 30 hari setelah tanam. Gulma harus disiangi setelah tanaman berumur antara 30-40 hari, bila dilakukan setelah tanaman berumur 40 hari, maka hasil tanaman tidak dapat diselamatkan. Periode kritis jagung manis berkompetisi dengan gulma pada entisol Lombok Tengan berada pada kisaran umur 30-40 hari setelah tanam. Tanaman bergulma selama 40, 50, dan 60 hari mengalami penurunan hasil sebanyak $60.32 \%, 82.84 \%$ dan $98.6 \%$. Sedangkan tanaman bebas gulma selama 10, 20 dan 30 hari mengalami penuruan hasil sebanyak $98.61 \%, 80.16 \%$ dan $61.40 \%$.
\end{abstract}

Kata Kunci: gulma; kompetisi; periode; kritis; biomas

\begin{abstract}
Weeds are not always detrimental to plants, because there is a period of time when they are most influential on plant growth and yield and a period of time when weeds are present is called critical piriode. A research aimed to determine the critical period of sweet corn with weeds in Central Lombok entisoles. The experimental research method with experiments in the field used a randomized block design (RBD), which consisted of 12 treatments, weed-free plants (TBG) from planting to age,
\end{abstract}


$10 ; 20 ; 30 ; 40 ; 50$ and 60 days and the plants were allowed to roll (TG). since planting until the age of $10 ; 20 ; 30 ; 40 ; 50$ and 60 days. The results showed that the presence of tolerable weeds on sweet corn plants was only until the age of 30 days after planting. Weeds must be weeded after the plants are between 30-40 days old, if done after the plants are 40 days old, the crop yields cannot be saved. The critical period for sweet corn competing with weeds on the Lombok Tengan entisol is in the age range between 30-40 days after planting. Plants that compete with weeds for 40, 50, and 60 days after planting (until harvest) experience a decrease in yield of $60.32 \%, 82.84 \%$ and $98.66 \%$. Meanwhile, plants that did not compete (weed free) for only 10, 20 and 30 days experienced a decrease in yield of $98.61 \%, 80.16 \%$ and $61.40 \%$.

Keyword: weeds; competitive; critical; period; biomass

\section{PENDAHULUAN}

Jagung manis atau sweet corn (Zea mays Saccharata Sturt.) termasuk dalam tanaman pangan penunjang, merupakan tipe jagung yang cukup lama telah dikembangkan masyarakat Indonesia. Jagung manis semakin populer dan banyak dikonsumsi karena memiliki rasa yang manis dibandingkan jagung biasa. Selain rasanya, keunggulan jagung manis adalah mempunyai nilai ekonomis yang tinggi di pasaran dan masa produksi yang relatif lebih cepat. Selain itu jagung manis dikelola lebih intensif dibanding produk pangan pokok lainnya, karena dikonsumsi dalam keadaan segar, tidak bisa disimpan lama, periode pemanfaatan/konsumsi yang pendek dan tidak tahan disimpan lama (Wilter et al., 2017. Produksi jagung sejak tahun 2017 s/d 2019 terus meningkat sejalan dengan semakin banyaknya permintaan. Rata-rata produksi jagung nasional tahun 2017 sebanyak 23,58 juta ton atau meningkat 20,22\% dari tahun 2016 sebesar 19,61 juta ton, dan produksi tahun 2018 meningkat 10,39\% menjadi 26,03 juta ton (BPS, 2019).

Jagung banyak diusahakan di Indonesia termasuk Lombok Nusa Tenggara Barat, yang tanahnya didominansi jenis entisol. Jenis tanah ini merupakan tanah muda yang berkembang dari bahan induk vulkanik yang cukup beragam. Sifat fisik entisol memiliki karakter yang khas bertekstur lempung ringan dari susunan 30\% pasir, 35\% debu dan $35 \%$ lempung, berstruktur kurang remah konsistensi liat lekat dan permeabilitas sedang. Bila dalam kondisi kering mudah pecah dan rengkah dan dalam kondisi basah liat dan sangan lengket. Jenis tanah ini relatif subur namun mempunyai tingkat jerapan $\mathrm{P}$ yang tinggi karena dirajap oleh mineral amorf seperti alofan, imogolit, ferihidrit dan oksida-oksida hidrat $\mathrm{Al}$ dan Fe dengan permukaan spesifik yang luas. Pada kondisi tertentu $\mathrm{pH}$ cendrung tinggi sehingga ketersediaan fosfat rendah, karena sebagian besar fosfat terikat oleh mineral liat alofan, Fe dan Al, sehingga menyebabkan rendahnya efisiensi pemupukan. Penambahan bahan organik ke dalam tanah dapat meningkatkan terlepasnya $\mathrm{P}$ dari partikel-partikel jerapan tanah oleh proses dekomposisi bahan organik tambahan (Bates and Lynch, 2001).

Salah satu aspek budidaya tanaman jagung manis yang sangat penting di wilayah ini adalah pengendalian terhadap gulma. Keadaan tanah yang kurang subur dan didukung oleh tipe iklim kering, menyebabkan jenis gulma yang tumbuh didominasi oleh teki, rumputrumputan dan gulma perdu yang sangat sulit dikendalikan (Ngawit, 2008). Dominannya jenis gulma tersebut karena memiliki ruang penyebaran yang luas, agresif dan sulit dikendalikan sehingga dampaknya sangat merugikan bila dibiarkan berada di sekitar tanaman. Berdasarkan nilai gangguannya beberapa jenis dari kelompok gulma teki dan rumput-rumputan termasuk golongan gulma ganas. Beberapa species dari kelompok ini menggunakan jalur metabolisme primer $\mathrm{C} 4$, yang berarti mampu tumbuh baik pada kondisi cekaman kekeringan, panas dan cahaya rendah seperti di bawah kanopi tanaman (Nurlaili, 2010). Khusus untuk teki, 
kapasitas regeneratif dan penyebaran umbi-umbinya juga sangat berkontribusi untuk keuntungan kompetitif. Organ tumbuhan teki yang tumbuh dari satu umbi mampu menghasilkan lebih dari 100 umbi dalam waktu sekitar 100 hari (Rahnavard et al., 2000). Umbi teki mampu bertahan dorman lebih dari 5 tahun dan bila kelembaban terjaga akan tumbuh normal. Hal ini menyebabkan gulma teki mendapat julukan gulma terburuk di dunia (Blum et al., 2000). Apabila keberadaan gulma pada tanaman jagung manis tidak dikendalikan dapat menurunkan hasil sampai $75 \%$ bahkan di wilayah lahan kering dapat menggagalkan panen total karena selain berkompetisi dengan tanaman jagung gulma dapat sebagai inang alternatif haman dan penyakit tanaman. Apabila gulma yang ada sebagai inang pengganti hama dan penyakit, maka penurunan hasil tanaman lebih cepat dan sangat merugikan. Namun demikian jenis-jenis gulma ganas tersebut dapat dikendalikan dan diminimalisir pertumbuhannya dengan penyiangan manual yang tepat waktu. Oleh karena itu maka telah dilakukan penelitian yang bertujuan untuk menentukan periode waktu keberadaan gulma pada pertanaman jagung manis yang tidak dapat ditolerir. Menentukan periode kritis jagung manis berkompeisi dengan gulma pada entisol Lombok Tengah.

\section{Bahan}

\section{METODE}

Bahan-bahan yang digunakan dalam kegiatan penelitian meliputi: Benih jagung manis Bonanza 9 F1 Cap Panah Merah. Pupuk NPK Ponska, Pupuk Urea, TSP dan ZA. Insektisida Sumialpha 250 EC dan fungisida Dithane M-45. Alat yang digunakan dalam kegiatan penelitian ini antara laian : cangkul, skop, kikis, cangkul garu, ember, gembor, gelas ukur, cawan petry, Erlenmeyer, Sprayer tipe Knapzax 16 1, alfaboard (penanda), mistar, hand counter, hand sprayer, kamera, dan alat tulis menulis..

\section{Metode dan Rancangan Percobaan}

Penelitian dilaksanakan mulai bulan Maret 2020 sampai bulan Juni 2020 di Desa Labulia, Kecamatan Jonggat, Kabupaten Lombok Tengah, Propinsi NTB. Metode penelitian yang digunakan eksperimental dengan percobaan di lapang menggunakan Rancangan Acak Kelompok (RAK), yang terdiri dari 6 perlakuan tanaman bebas bergulma (TBG) sejak tanam sampai umur 10;20;30; 40; 50; dan 60 HST dan 6 perlakuan tanaman bergulma (TG) sejak tanam sampai umur $10 ; 20 ; 30 ; 40 ; 50$; dan 60 HST. Masing-masing petak perlakuan luasnya $2 \mathrm{~m} \times 2,5 \mathrm{~m}$ yang ditempatkan secara acak pada 3 blok, sehingga ada 36 unit percobaan.

Variabel pertumbuhan dan hasil tanaman yang diamati meliputi, tinggi tanaman, luas daun, diameter tongkol, panjang tongkol, bobot tongkol per tanaman, bobot tongkol per petak dan bobot biomasa kering tanaman per petak. Pengematan tinggi dan luas daun tanaman dilakukan saat tanaman berumur 15, 30 dan 45 HST. Sedangkan pengamatan hasil tanaman dilakukan saat panen, yaitu umur tanaman 60 HST. Pengamatan variabel pertumbuhan dan populasi gulma dilakukan dengan mengukur bobot berangkasan kering (biomas) gulma saat tanaman berumur 60 HST. Sedangkan pengamatan populasi gulma dilakukan sebanyak tiga kali yaitu pada saat tanaman berumur 15 HST, 30 dan 45 HST. Petak sampel pengamatan gulma ditentukan berdasarkan metode sampling beraturan sebanyak lima petak sampel dengan luas masing-masing petak $0,5 \mathrm{~m} 2$. Metode pengukuran populasi gulma dilakukan dengan metode kuadrat sensus, yaitu dengan menghitung nilai parameter kerapatan nisbi, frekuensi nisbi, dominansi nisbi untuk menentukan perbandingan dominansi terjumlah (Sumed dominance ratio) dari masing-masing jenis gulma, dengan tahap-tahap perhitungan sebagai berikut (Ngawit, 2008) : 
1. Kerapatan mutlak suatu jenis gulma dinyatakan sebagai jumlah individu jenis gulma dalam setiap petak sampel. Seadangkan kerapatan nisbi $(\mathrm{Kn})$ dari suatu jenis gulma dinyatakan sebagai :

$K n=\left(\right.$ Kerapatan mutlak suatu jenis) $(\text { Jumlah kerapatan mutlak semua jenis })^{-1} \times 100 \%$.

2. Frekuensi mutlak suatu jenis gulma dinyatakan sebagai jumlah petak contoh yang memuat jenis itu dibagi dengan jumlah semua petak contoh yang dipakai. Sedangkan frekuensi nisbi (Fn) suatu jenis gulma dinyatakan sebagai berikut :

$F n=($ Frekuensi mutlak suatu jenis $)(\text { Jumlah frekuensi mutlak semua jenis })^{-1} \times 100 \%$.

3. Dominansi mutlak suatu jenis dihitung dihitung berdasarkan ukuran volume dari jenis gulma tersebut. Voleme $=$ Luas basal $\mathrm{x}$ rata-rata tinggi $\mathrm{x}$ jumlah jenis. Dominansi nisbi (Dn) dinyatakan sebagai berikut :

Dn $=($ ominansi mutlak suatu jenis $)(\text { Jumlah dominansi mutlak semua jenis })^{-1} \times 100 \%$

4. SDR (Sumed dominance ratio) : merupakan nilai rata-rata nlai nisbi ketiga parameter yang telah dihitung.

$S D R=(K n+F n+D n): 3$

\section{Analisis data}

Data yang diperoleh dianalisis menggunakan analisis varian dan apabila terdapat beda nyata antar perlakuan dilanjutkan dengan uji BNJ pada taraf 5\%. Respons pertumbuhan dan hasil jagung manis serta gulma dari beberapa perlakuan tanman bergulma dan bebas gulma, dianalisis menurut model regresi/korelasi menggunakan Microsoft Excel dan Minitab for Windows. Data berat biomas kering tanaman per petak dan berat kering gulma dianalisis menggunakan uji nonparametric dengan William's Test dengan uji statistik (Purwanti et al., 2012) :

$\mathrm{tk}=(\mathrm{Mk}-\mathrm{X} 0)\left(\mathrm{sk}^{2} / \mathrm{r}+\mathrm{X} 0^{2} / \mathrm{r}\right)-1 / 2$

Keterangan:

tk = hasil uji-t

$\mathrm{sk}^{2}=$ varian perlakuan

$\mathrm{X} 0=$ hasil perlakuan control

$\mathrm{r} \quad=$ jumlah blok.

$\mathrm{Mk}=$ hasil rata-rata proses perlakuan

\section{HASIL DAN PEMBAHASAN}

Pengaruh periode tanaman bebas gulma dn bergulma terhadap populasi dan pertumbuhan Gulma sebelum percobaan, ditemukan 15 jenis gulma yang dominan, yang terdiri atas 8 jenis berdaun lebar, 6 rumput-rumputan (Poaceae) dan 1 jenis teki. Pengamatan populasi dan pertumbuhan jenis-jenis gulma setelah aplikasi perlakuan menunjukkan bahwa tidak semua jenis gulma yang ditemukan sebelum percobaan, ditemukan kembali pada masing-masing perlakuan. Ada 12 jenis gulma yang selalu muncul pada setiap perlakuan, tetapi hanya beberapa jenis yang dominan. Populasi dan dominansi jenis-jenis gulma pada masing-masing perlakuan disajikan pada Gambar 1 dan 2 berikut. 


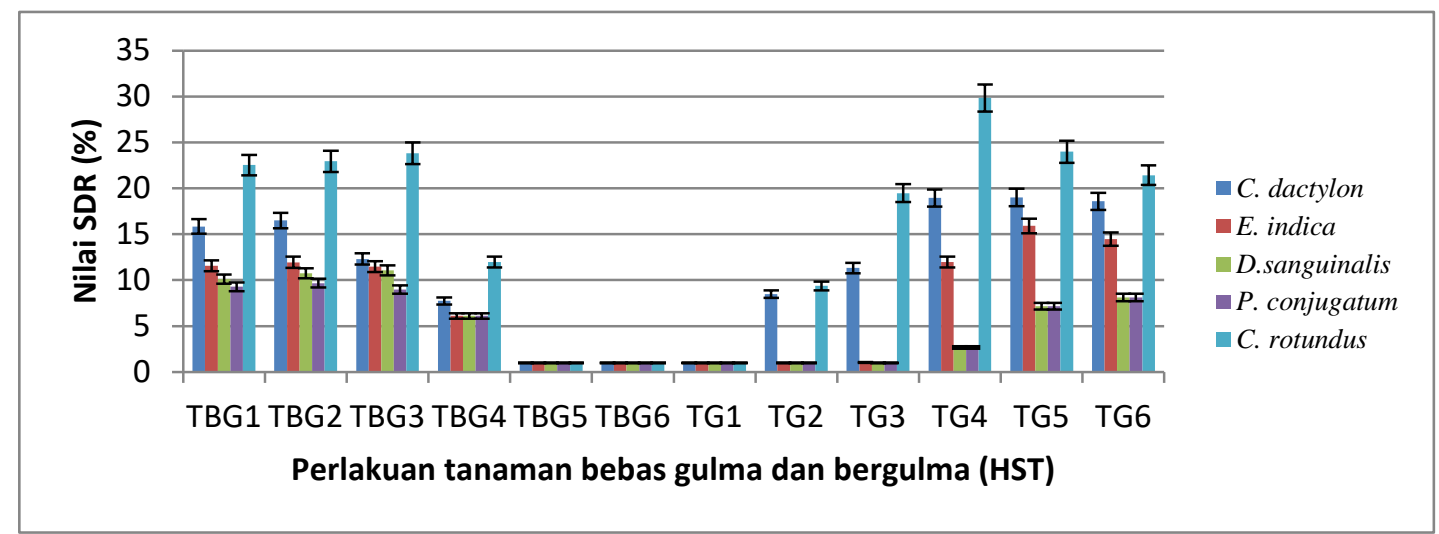

Gambar 1. Pengaruh periode waktu tanaman bebas gulma dan bergulma terhadap nilai SDR gulma rumput-rumputan dan teki

Penyiangan gulma pada setiap perlakuan yang berbeda-beda menyebabkan populasi dan dominansi masing-masing jenis gulma merbeda-beda. Pada perlakuan tanaman bergulma selama $40 \mathrm{HST}\left(\mathrm{TG}_{4}\right), 50 \mathrm{HST}\left(\mathrm{TG}_{5}\right)$ dan $60 \mathrm{HST}\left(\mathrm{TG}_{6}\right)$, serta tanaman yang bebas gulma sejak tanam selama $10 \mathrm{HST}\left(\mathrm{TBG}_{1}\right), 20 \mathrm{HST}\left(\mathrm{TBG}_{2}\right)$ dan $30 \mathrm{HST}\left(\mathrm{TBG}_{3}\right)$ selalu ditemukan 12 jenis gulma dominan, dengan rician 4 jenis Poaceae dan 1 jenis teki (Gambar 1), dan 7 berdaun lebar dan perdu (Gambar 2). Sedangkan pada perlakuan tanaman yang mengalami bebas gulma selama tumbuhnya $60 \mathrm{HST}\left(\mathrm{TBG}_{6}\right)$ dan selama $50 \mathrm{HST}\left(\mathrm{TBG}_{5}\right)$ serta pada perlakuan tanaman yang bergulma selama $10 \mathrm{HST}\left(\mathrm{TG}_{1}\right)$ dan $20 \mathrm{HST}\left(\mathrm{TG}_{2}\right)$, terjadi penekanan total populasi dan pertumbuhan gulma karena tidak ditemukan gulma yang tumbuh efektif berkompetisi dengan tanaman.

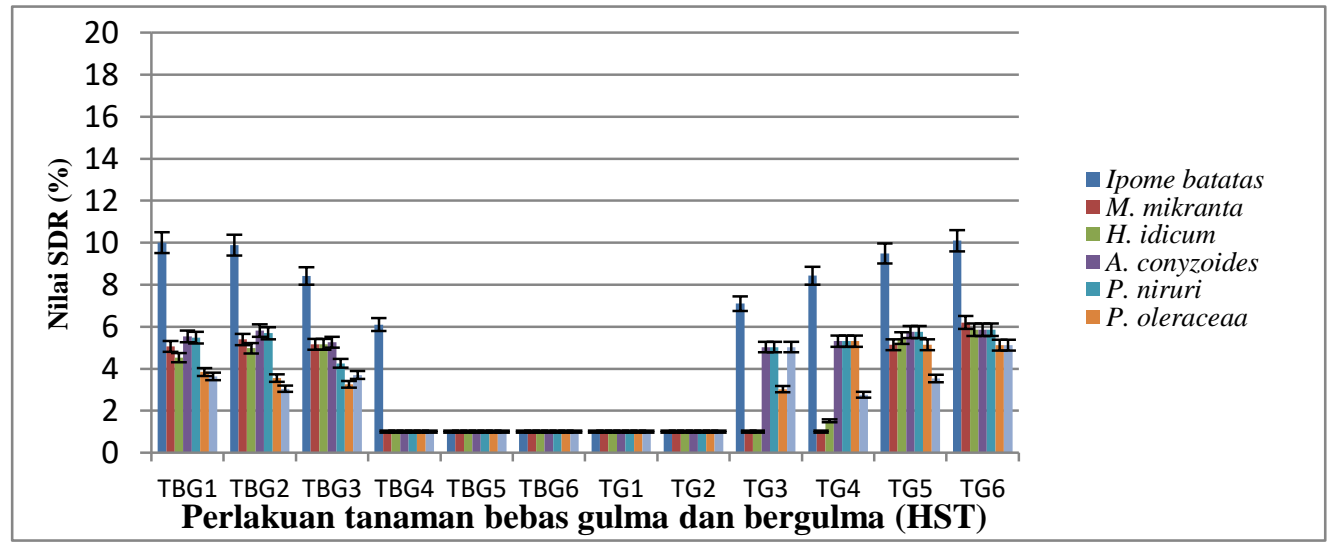

Gambar 2. Pengaruh periode waktu tanaman bebas gulma dan bergulma terhadap nilai SDR gulma berdaun lebar dan perdu

Penekanan total populasi dan pertumbuhan gulma mulai berkurang pada perlakuan tanaman yang mengalami bebas gulma selama $40 \mathrm{HST}\left(\mathrm{TBG}_{4}\right)$ dan bergulma selama $30 \mathrm{HST}$ $\left(\mathrm{TG}_{3}\right)$. Pada periode itu, tanaman jagung manis sudah mulai berkompetisi dengan gulma sehingga pertumbuhannya tampak sudah mulai terganggu/terhambat. Beberapa jenis gulma yang memberi tekanan signifikant terhadap nilai dominansi terjumlah (SDR) jagung adalah C. Rotondus, C. dactylon dan Ipome batatas, dengan selisih nilai SDR antara jagung dengan gulma tersebut lebih dari $10 \%$. Ega et al. (2018), menyatakan bahwa gulma teki dan beberapa familia Poaceae bila disiangi lebih awal yaitu saat tanaman jagung berumur 21-28 HST, populasi dan pertumbuhannya dapat ditekan maksimal. Namun bila penyiangannya 
terlambat sampai umur tanaman 30 HST, pertumbuhan dan hasil tanaman dapat teredguksi lebih dari $75 \%$.

Keefiktifan penyiangan terhadap penekanan pertumbuhan gulma secara total pada perlakuan $\mathrm{TBG}_{5}, \mathrm{TBG}_{6}, \mathrm{TG}_{1}$ dan $\mathrm{TG}_{2}$ berpengaruh positif terhadap tinggi dan luas daun tanaman (Tabel 1). Rata-rata tinggi dan luas dauan tanaman saat tanaman berumur 15 HST tidak berbeda nyata pada semua perlakuan, tetapi pada umur 30 dan 45 HST rata-rata tinggi dan luas daun tanaman pada keempat perlakuan tersebut nyata lebih tinggi dibandingkan dengan perlakuan lainnya. Pada umur 15 HST tanaman jagung manis belum merespon pengaruh keberadaan gulma di sekitar tumbuhnya sehingga semua perlakuan tanaman bergulma dan bebas gulma tidak berpengaruh terhadap tinggi dan luas dauan tanaman. Hal ini sesuai dengan pendapat Wilter at al. (2017), bahwa tanaman yang mengalami penyiangan/bebas gulma sampai umur 14 HST atau tanpa penyiangan tidak berpengaruh terhadap pertumbuhan tanaman.

Tabel 1. Pengaruh periode tanaman bebas gulma dan bergulma terhadap pertumbuhan rata-rata tinggi tanaman $(\mathrm{cm})$ dan luasdauan $\left(\mathrm{cm}^{2)}\right.$ jagung manis umur 15, 30 dan 45 HST.

\begin{tabular}{|c|c|c|c|c|c|c|}
\hline \multirow[t]{2}{*}{ Perlakuan } & \multicolumn{3}{|c|}{ Tinggi tanaman $(\mathrm{cm})$ saat berumur } & \multicolumn{3}{|c|}{ Luas daun $(\mathrm{cm} 2)$ saat berumur } \\
\hline & 15 & 30 & 45 & 15 & 30 & 45 \\
\hline $\mathrm{TBG}_{1}$ & $24.493 \mathrm{a}$ & 36.413 ef & $56.453 \mathrm{~d}$ & $56.136 \mathrm{a}$ & $56.523 \mathrm{~g}$ & $57.623 \mathrm{~h}$ \\
\hline $\mathrm{TBG}_{2}$ & $.530 \mathrm{a}$ & $37.443 \mathrm{e}$ & $53.330 \mathrm{e}$ & $56.076 \mathrm{a}$ & $72.430 \mathrm{e}$ & $78.120 \mathrm{f}$ \\
\hline $\mathrm{TBG}_{3}$ & $1.496 \mathrm{a}$ & $50.043 \mathrm{c}$ & $60.230 \mathrm{c}$ & $56.123 \mathrm{a}$ & $140.143 \mathrm{~d}$ & $160.233 \mathrm{~d}$ \\
\hline $\mathrm{TBG}_{4}$ & $.473 \mathrm{a}$ & $92.123 \mathrm{~b}$ & $124.853 \mathrm{~b}$ & $56.093 \mathrm{a}$ & $192.223 \mathrm{~b}$ & $274.830 \mathrm{~b}$ \\
\hline $\mathrm{TBG}_{5}$ & $.513 \mathrm{a}$ & $111.543 \mathrm{a}$ & $150.083 \mathrm{a}$ & $56.033 \mathrm{a}$ & $222.133 \mathrm{a}$ & $350.333 \mathrm{a}$ \\
\hline $\mathrm{TBG}_{6}$ & $.506 \mathrm{a}$ & $111.483 \mathrm{a}$ & $150.253 \mathrm{a}$ & $56.096 \mathrm{a}$ & $222.230 \mathrm{a}$ & $350.766 \mathrm{a}$ \\
\hline $\mathrm{TG}_{1}$ & $4.476 \mathrm{a}$ & $111.533 \mathrm{a}$ & $150.333 \mathrm{a}$ & $56.113 \mathrm{a}$ & $222.143 \mathrm{a}$ & $350.266 \mathrm{a}$ \\
\hline $\mathrm{TG}_{2}$ & $.506 \mathrm{a}$ & $111.513 \mathrm{a}$ & $150.316 \mathrm{a}$ & $55.973 \mathrm{a}$ & $222.123 \mathrm{a}$ & $350.466 \mathrm{a}$ \\
\hline $\mathrm{TG}_{3}$ & $.496 \mathrm{a}$ & $91.833 \mathrm{~b}$ & $125.453 \mathrm{~b}$ & $56.230 \mathrm{a}$ & $191.923 \mathrm{~b}$ & $225.433 \mathrm{c}$ \\
\hline $\mathrm{TG}_{4}$ & $24.483 \mathrm{a}$ & $48.653 \mathrm{~d}$ & $56.163 \mathrm{~d}$ & $56.006 \mathrm{a}$ & $148.643 \mathrm{c}$ & $156.230 \mathrm{e}$ \\
\hline $\mathrm{TG}_{5}$ & $24.513 \mathrm{a}$ & 36.753 ef & $57.033 \mathrm{~d}$ & $56.223 \mathrm{a}$ & $66.723 \mathrm{f}$ & $72.233 \mathrm{~g}$ \\
\hline $\mathrm{TG}_{6}$ & $24.493 \mathrm{a}$ & $36.153 \mathrm{f}$ & $52.750 \mathrm{e}$ & $56.033 \mathrm{a}$ & $56.223 \mathrm{~g}$ & $58.130 \mathrm{~h}$ \\
\hline $\mathrm{BNJ}_{0.05}$ & 0.04371 & 0.6627 & 0.8048 & 0.3883 & 0.9456 & 0.9946 \\
\hline
\end{tabular}

Keterangan: Angka pada kolom yang sama diikuti oleh huruf yang sama tidak berbeda nyata pada uji BNJ 0.05 .

Bila dikaitkan antara pertumbuhan tinggi dan luas daun tanaman, dengan bobot biomas kering tanaman serta bobot biomas kering gulma, perlakuan tanaman bergulma 0-10 HST $\left(\mathrm{TG}_{1}\right), 0-20 \mathrm{HST}\left(\mathrm{TG}_{2}\right)$, bebas gulma sampai umur $50 \mathrm{HST}\left(\mathrm{TGB}_{5}\right)$ dan $60 \mathrm{HST}\left(\mathrm{TGB}_{6}\right)$ ternyata menunjukkan trend yang sama, bahwa rata-rata bobot biomas kering tanaman nyata lebih tinggi dibanding dengan perlakuan lainnya. Namun demikian terjadi sebaliknya terhadap bobot biomas kering gulma yang pada perlakuan tersebut nyata lebih rendah dengan hasil mendekati 0,0. (Tabel 2).

Bobot biomas kering gulma merupakan ukuran yang tepat untuk mempredisi sarana tumbuh yang telah diserap oleh gulma. Rata-rata tinggi tanaman dan luas daun yang nilainya nyata lebih tinggi pada keempat perlakuan tersebut mampu menekan pertumbuhan gulma terutama kelompok Poaceae dan Teki. Akibatnya organ-organ vegetatif gulma semakin berkurang sehingga potensinya untuk tumbuh terhambat yang pada akhirnya bobot biomas keringnya juga rendah. Rata-rata luas daun tanaman yang lebih luas tentu kanopinya dapat menutupi areal pertanaman dengan baik, selain itu luas dauan tanaman, penting artinya bagi pertumbuhan karena daun merupakan organ tanaman yang penting untuk proses fotosistesis. 
Apabila nilai rata-rata luas daun yang dihasilkan rendah seperti pada perlakuan tanaman mengalami bergulma sejak awal tumbuhnya sampai umur 40, 50 dan $60 \mathrm{HST}$ ( $\mathrm{TG}_{4}, \mathrm{TG}_{5}$, dan $\left.\mathrm{TG}_{6}\right)$, serta bebas gulma hanya sampi umur $20 \mathrm{HST}\left(\mathrm{TBG}_{1}\right.$ dan $\left.\mathrm{TBG}_{2}\right)$, maka fotosintat yang dihasilkan juga rendah, sementara hasil fotosintat (karbohidrat) sangat penting sebagai sumber energi pertumbuhan. Bobot biomas kering tanaman yang paling tinggi diperoleh pada perlakuan tanaman mengalami bebas gulma sejak awal pertumbuhan sampai umur 50 dan 60 HST dan pada perlakuan tanaman bergulma hanya sampai umur 20 HST.

Berkurangnya luas dau cendrung menyebabkan menurunnya bobot biomas kering tanaman, kemudian berdampak terhadap penurunan pertumbuhan dan hasil total tanaman. Rendahnya ketersediaan cahaya matahari yang dapat diserap oleh daun tanaman untuk mendukung fotosintesis menyebabkan biomas yang dihasilkan menjadi rendah. Lebar atau sempitnya luas daun tanaman juga dapat mempengaruhi pertumbuhan gulma di sekitar tanaman, karena jika semakin sempit luas daun tanaman maka semakin banyak sinar matahari yang dapat masuk untuk menuju kepermukaan tanah. Hal ini terbukti dari hasil pengamatan bobot biomas kering gulma pada perlakuan $\mathrm{TBG}_{5}, \mathrm{TBG}_{6}, \mathrm{TG}_{1}$ dan $\mathrm{TG}_{2}$ yang diperoleh nyata lebih rendah dibandingkan dengan perlakuan lainnya (Tabel 2).

Berdasarkan hasil pengamatan komponen pariabel hasil tanaman tampak bahwa, hasil yang tertinggi diperoleh pada perlakuan $\mathrm{TBG}_{6}, \mathrm{TBG}_{5}, \mathrm{TG}_{1}$, dan $\mathrm{TG}_{2}$. Penurunan hasil tanaman pada perlakuan $\mathrm{TBG}_{5}, \mathrm{TG}_{1}$, dan $\mathrm{TG}_{2}$ tidak berarti. Penurunan hasil tanaman yang terbanyak terjadi pada perlakuan tanaman bergulma selama tumbuhnya $\left(\mathrm{TB}_{6}\right)$, kemudian disusul perlakuan tanaman bergulma $50 \mathrm{HST}\left(\mathrm{TG}_{5}\right)$, $40 \mathrm{HST}\left(\mathrm{TG}_{4}\right)$, dan tanaman yang bebas gulma sejak awal pertumbuhannya sampai umur $10 \mathrm{HST}\left(\mathrm{TBG}_{1}\right), 20 \mathrm{HST}\left(\mathrm{TBG}_{2}\right)$ dan 30 $\mathrm{HST}\left(\mathrm{TBG}_{3}\right)$.

Tabel 2. Pengaruh periode tanaman bebas gulma dan bergulma terhadap rata-rata bobot biomas kering tanaman per petak (gr), bobot biomas kering gulma per petak (g), bobot tongkol segar per tanaman dan per petak, panjang tongkol dan diameter tongkol saat tanaman jagung manis umur $60 \mathrm{HST}$.

\begin{tabular}{|c|c|c|c|c|c|c|}
\hline Perlakuan & $1 /$ & $2 /$ & $\underline{3 /}$ & $4 /$ & $5 /$ & $6 /$ \\
\hline $\mathrm{TBG}_{1}$ & $0.053 \mathrm{e}$ & $1682.063 \mathrm{a}$ & $0.053 \mathrm{~d}$ & $0.053 \mathrm{e}$ & $0.053 \mathrm{~d}$ & $0.005 \mathrm{~d}$ \\
\hline $\mathrm{TBG}_{2}$ & $4.223 \mathrm{~d}$ & $1664.823 \mathrm{~b}$ & $0.053 \mathrm{~d}$ & $0.053 \mathrm{e}$ & $0.053 \mathrm{~d}$ & $0.005 \mathrm{~d}$ \\
\hline $\mathrm{TBG}_{3}$ & $286.286 \mathrm{c}$ & $982.330 \mathrm{c}$ & $99.336 \mathrm{c}$ & $1.443 \mathrm{~d}$ & $13.483 \mathrm{c}$ & $7.243 \mathrm{c}$ \\
\hline $\mathrm{TBG}_{4}$ & $1204.523 b$ & $5.223 \mathrm{~d}$ & $152.873 \mathrm{~b}$ & $3.433 \mathrm{c}$ & $17.733 \mathrm{ab}$ & $8.630 \mathrm{a}$ \\
\hline $\mathrm{TBG}_{5}$ & $1560.043 a$ & $0.053 \mathrm{e}$ & $167.743 \mathrm{a}$ & $4.443 \mathrm{~b}$ & $17.733 \mathrm{ab}$ & $8.816 \mathrm{a}$ \\
\hline $\mathrm{TBG}_{6}$ & $1560.130 \mathrm{a}$ & $0.053 \mathrm{e}$ & $167.833 \mathrm{a}$ & $4.733 \mathrm{a}$ & $17.830 \quad \mathrm{a}$ & $8.953 \mathrm{a}$ \\
\hline $\mathrm{TG}_{1}$ & $1560.05 \mathrm{a}$ & $0.053 \mathrm{e}$ & $167.823 \mathrm{a}$ & $4.530 \mathrm{~b}$ & $17.630 \mathrm{ab}$ & $8.843 \mathrm{a}$ \\
\hline $\mathrm{TG}_{2}$ & $1560.30 \mathrm{a}$ & $0.053 \mathrm{e}$ & $167.743 \mathrm{a}$ & $4.463 \mathrm{~b}$ & $17.223 \mathrm{~b}$ & $8.763 \mathrm{a}$ \\
\hline $\mathrm{TG}_{3}$ & $1204.23 b$ & $5.423 \mathrm{~d}$ & $152.766 \mathrm{~b}$ & $3.430 \mathrm{c}$ & $17.373 \mathrm{ab}$ & $8.663 \mathrm{~b}$ \\
\hline $\mathrm{TG}_{4}$ & $286.46 c$ & $978.723 c$ & $99.306 \mathrm{c}$ & $1.453 \mathrm{~d}$ & $13.506 \mathrm{c}$ & $7.233 \mathrm{c}$ \\
\hline $\mathrm{TG}_{5}$ & $4.223 \mathrm{~d}$ & $1664.223 b$ & $0.053 \mathrm{~d}$ & $0.053 \mathrm{e}$ & 0.053 & $0.005 \mathrm{~d}$ \\
\hline $\mathrm{TG}_{6}$ & $0.053 \mathrm{e}$ & $1682.343 a$ & $0.053 \mathrm{~d}$ & $0.053 \mathrm{e}$ & $0.053 \mathrm{~d}$ & $0.005 \mathrm{~d}$ \\
\hline $\mathrm{BNJ}_{0.05}$ & 1.3121 & 2.0693 & 0.3385 & 0.388 & 0.9456 & 0.9946 \\
\hline
\end{tabular}

Keterangan : Angka pada kolom yang sama diikuti oleh huruf yang sama tidak berbeda nyata pada uji BNJ $0.05 ; \underline{1} /=$ =Bobot biomas kering tanaman $\operatorname{petak}^{1}(\mathrm{gr}) ; \underline{2} /=$ Bobot biomas kering gulma petak ${ }^{1}(\mathrm{gr}) ; \underline{3} /=$ Bobot tongkol $\operatorname{tanaman}^{-1}(\mathrm{gr}) ; \underline{4} /=$ Bobot tongkolpetak $^{-1} ; \underline{5} /=$ Panjang tongkol $(\mathrm{cm}) ; \underline{6} /=$ Diameter tongkol $(\mathrm{cm})$. 
Berdasarkan parameter pengamatan bobot tongkol per petak, penurunan hasil jagung manis pada perlakuan $\mathrm{TG}_{6}, \mathrm{TG}_{5}$ dan $\mathrm{TG}_{4}$ sebanyak $98,66 \%, 82,84 \%$ dan $60,32 \%$. Sedangkan penuruan hasil jagung manis pada perlakuan $\mathrm{TBG}_{1}, \mathrm{TBG}_{2}$ dan $\mathrm{TBG}_{3}$ sebanyak 98,66\%, 80,16 $\%$ dan $61,40 \%$. Tampaknya penurunan hasil tanaman yang nyata (melebihi 50\%) dimulai dari tanaman yang bergulma sejak awal tumbuhnya sampai umur 40 hari $\left(\mathrm{TG}_{4}\right)$ dan tanaman bebas gulma sampai umur $30 \mathrm{HST}\left(\mathrm{TBG}_{3}\right)$. Sebaliknya tanaman yang mengalami bebas gulma sampai umur $40 \mathrm{HST}\left(\mathrm{TBG}_{4}\right)$ dan bergulma sampai umur $30 \mathrm{HST}\left(\mathrm{TG}_{3}\right)$ mengalami penurunan hasil yang tidak berarti, yaitu untuk perlakuan $\mathrm{TBG}_{4}$, dan $\mathrm{TBG}_{5}$ hanya sebanyak $7,78 \%$ dan $8,04 \%$ sedangkan pada perlakuan $\mathrm{TG}_{1}, \mathrm{TG}_{2}$ dan $\mathrm{TG}_{3}$ sebanyak $6,16 \% ; 7,23 \%$ dan $8,85 \%$. Jadi dapat dinyatakan bahwa tanaman tidak menglami hambatan pertumbuhan atau penurunan hasil nyata bila berkopetinsi dengan gulma selama periode umur 20-30 hari. Efetktivitas pengendalian gulma sangat ditentukan oleh ketepatan dalam menentulan waktu pelaksanannya dan cara pengendalian gulma yang diterapkan (Setiawan at al., 2014). Bila tanaman bebas gulma pada periode umur terntu diharapkan pertumbuhan tanaman akan optimal meskipun pada periode-periode umur yang lainnya keberadaan gulma tetap dibiarkan. Sehubungan dengan hal itu, maka pelaksanaan waktu penyiangan yang lebih cepat atau penyiangan pertama dapat mempengaruhi populasi gulma berikutnya sehingga kehilangan hasil tanaman dapat dihindari (Galon and Agostinetto, 2009). Dinyatakan pula oleh Gibson et al. (2002), bahwa tanaman dapat tumbuh optimal bila gulma dikendalikan pada saat awal pertumbuhannya, sehingga mampu meningkatkan daya saingnya dalam berkompetisi dengan gulma. Dinyatakan pula bahwa persaingan antara gulma dan tanaman dipengaruhi oleh waktu dan lama periode umur tanaman bersaing dengan gulma. Selanjutnya Nedim et al. (2004), mempertegas pernyataan tersebut bahwa, tanaman jagung khususnya jagung manis sangat peka terhadap saingan gulma pada awal pertumbuhannya.

\section{Periode Kritis Tanaman Jagung Manis Berkompetisi dengan Gulma}

Periode tumbuh tanaman budidaya dan gulma berada dalam keadaan saling berkompetisi secara aktif disebut periode kritis. Apabila masa kritis kompetisi pada awal pertumbuhan dapat dikendalikan maka masa kritis pada tahap pertumbuhan berikutnya tidak terjadi sehingga hasil tanaman yang diperoleh optimal (Zimdahl, 1980).

Tabel 3. Hasil analisis t-William bobot biomas kering jagung manis dan gulma antara perlakuan tanaman bergulma dan bebas gulma

\begin{tabular}{|c|c|c|c|}
\hline \multicolumn{2}{|c|}{$\begin{array}{l}\text { Bobot biomas kering tanaman pada } \\
\text { perlakuan }\left(\mathrm{TBG}_{6}\right) \text { sebagai pembanding }\end{array}$} & \multicolumn{2}{|c|}{$\begin{array}{l}\text { Bobot biomas kering gulma pada perlakuan } \\
\left(\mathrm{TG}_{6}\right) \text { sebagai pembanding }\end{array}$} \\
\hline Perlakuan & Hasil Uji t-willam & Perlakuan & Hasil Uji t-willam \\
\hline $\mathrm{TBG}_{1}$ & $11207,4714 * \mathrm{*}$ & $\mathrm{TBG}_{1}$ & $0,0000 \mathrm{~ns}$ \\
\hline $\mathrm{TBG}_{2}$ & $5852,7949 * \mathrm{~s}$ & $\mathrm{TBG}_{2}$ & $0,0000 \mathrm{~ns}$ \\
\hline $\mathrm{TBG}_{3}$ & $3213,2886 *_{s}$ & $\mathrm{TBG}_{3}$ & $836,6656 *_{s}$ \\
\hline $\mathrm{TBG}_{4}$ & $80,0498 *_{\mathrm{s}}$ & $\mathrm{TBG}_{4}$ & $3846,2172 * s$ \\
\hline $\mathrm{TBG}_{5}$ & $0,0000 \mathrm{~ns}$ & $\mathrm{TBG}_{5}$ & $4075,3888 * \mathrm{~s}$ \\
\hline $\mathrm{TBG}_{6}$ & $0,0000 \mathrm{~ns}$ & $\mathrm{TBG}_{6}$ & $4075,3888 *_{\mathrm{s}}$ \\
\hline $\mathrm{TG}_{1}$ & $0,0000 \mathrm{~ns}$ & $\mathrm{TG}_{1}$ & $4075,3888 *_{\mathrm{s}}$ \\
\hline $\mathrm{TG}_{2}$ & $0,0000 \mathrm{~ns}$ & $\mathrm{TG}_{2}$ & $4075,3888 *_{\mathrm{s}}$ \\
\hline $\mathrm{TG}_{3}$ & $544,1896 *_{\mathrm{s}}$ & $\mathrm{TG}_{3}$ & $2686,9411 *_{s}$ \\
\hline $\mathrm{TG}_{4}$ & $3354,2268 *_{\mathrm{s}}$ & $\mathrm{TG}_{4}$ & $789,1009 \mathrm{~ns}$ \\
\hline $\mathrm{TG}_{5}$ & $1413,4793 *_{\mathrm{s}}$ & $\mathrm{TG}_{5}$ & $0,0000 \mathrm{~ns}$ \\
\hline $\mathrm{TG}_{6}$ & $11207,4714 *_{\mathrm{s}}$ & $\mathrm{TG}_{6}$ & $0,0000 \mathrm{~ns}$ \\
\hline $\mathrm{t}_{\text {tabel } 0.05}$ & 12,70620 & $\mathrm{t}_{\text {tabel } 0.05}$ & 12,70620 \\
\hline
\end{tabular}


Uji t-William dilakukan untuk mengetahui periode waktu pertanaman jagung manis harus bersih/bebas dari gulma sejak tanam, dan kapan keberadaan gulma di pertanaman boleh dibiarkan (Tabel 3). Selain itu dianalis juga hubungan antara bobot biomas kering gulma dengan bobot kering biomas tanaman dan bobot tongkol tanpa klobot menggunakan analisis regresi kolrelasi polynominal, untuk menentukan waktu yang tepat kehadiran gulma pada areal pertanaman sudah tidak dapat ditolerir.

Hasil analisis uji t-William berdasarkan bobot biomas kering tanaman pada perlakuan tanaman bebas gulma selama $60 \mathrm{HST}\left(\mathrm{TBG}_{6}\right)$ sebagai pembanding (Tabel 3) menunjukkan bahwa akibat kompetisi dengan gulma, tidak ada respon tanaman jagung manis pada perlakuan tanaman bebas gulma selama 50 HST dan 60 HST dan tanaman bergulma selama 10 dan 20 HST. Respon negatif atau mulai terjadi penurunan hasil pada perlakuan tanaman bebas gulma selama 40, 30, 20 dan 10 HST, dan tanaman bergulma selama 30,40,50 dan 60 HST. Jika berdasarkan bobot biomas kering gulma pada perlakuan tanaman bergulma sejak tanam sampai panen sebagai pembanding $\left(\mathrm{TG}_{6}\right)$, ternyata tidak terjadi penurunan yang berarti populasi dan pertumbuhan gulma pada perlakuan tanaman bebas gulma 10 HST sampai umur 20 HST dan tanaman bergulma selama 50 HST dan 60 HST. Pertumbuhan dan populasi gulma mulai mengalami penurunan pada perlakuan tanaman bebas gulma 30, 40, 50 dan 60 HST dan pada perlakuan tanaman bergulma 10, 20, 30 dan 40 HST. Hal ini menunjukkan keberadaan gulma sampai umur tanaman 30 - 40 HST merupakan periode kritis dari tanaman berkompetisi dengan gulma dan kehadiran gulma harus disiang, agar tidak terjadi penurunan hasil jagung manis. Membiarkan gulma tumbuh pada areal tanaman pada periode umur tersebut dan baru melakukan penyiangan saat umur tanaman 40 hari, menyebabkan pertumbuhan tanaman jagung manis tidak bisa dikembalikan ke fase normal serta hasil tanaman tidak dapat dipertahankan.

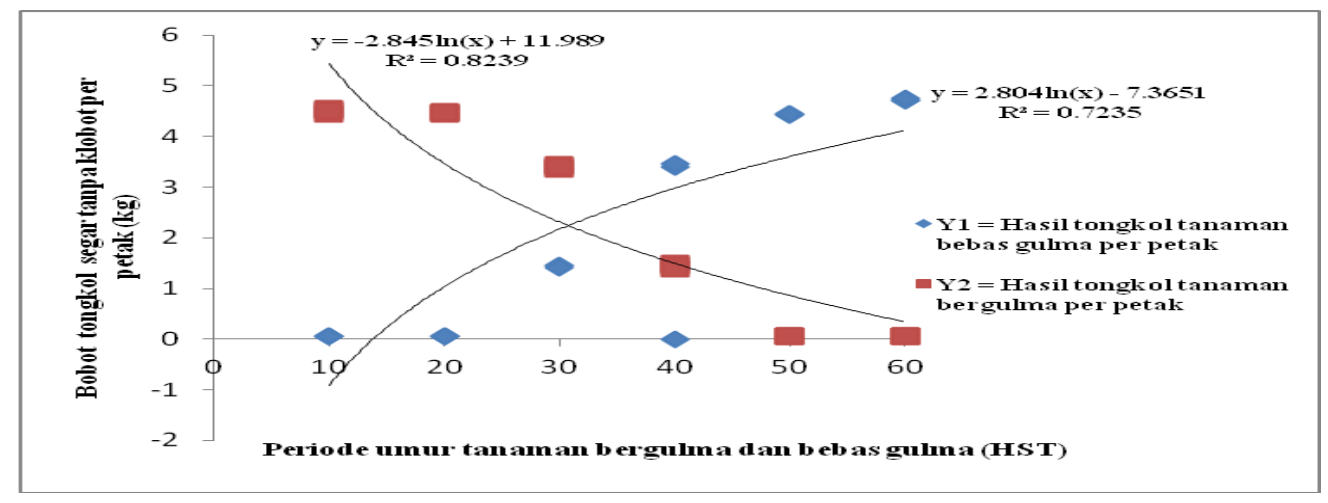

Gambar 1. Pengaruh periode umur tanaman bergulma dan bebas gulma terhadap kenaikan dan penurunan hasil tongkol jagug petak ${ }^{-1}$

Hasil analisis uji t-William tersebut dipertegas oleh hasil regresi korelasi antara periode umur tanaman bergulma dan bebas gulma dengan hasil tanaman jagung per petak. Perpotongan garis polynominal antara hasil tongkol tanaman bergulma dengan bebas gulma, terjadi pada saat tanaman berumur 30 HST dan tampak pula garis hubungan polynominal tersebut menunjukkan tanaman bergulma $\left(\mathrm{Y}_{2}\right)$ selama 30-40 HST mengalami penurunan hasil yang tajam, sehingga bila gulma dibiarkan sampai umur tanaman 40 HST, maka tanaman tidak bisa diselamatkan. Hal sebaliknya, bila tanaman mengalami bebas gulma $\left(\mathrm{Y}_{1}\right)$ kurang dari 30 hari juga menunjukkan trend menurunan hasil yang tajam (Gambar 1). Trend yang sama tampak pula perpotongan garis polyniminal antara hasil berat kering biomas 
jagung pada perlakuan tanaman bergulma dengan perlakuan tanaman bebas gulma terjadi pula saat tanaman berumur 30 HST (Gambar 2).

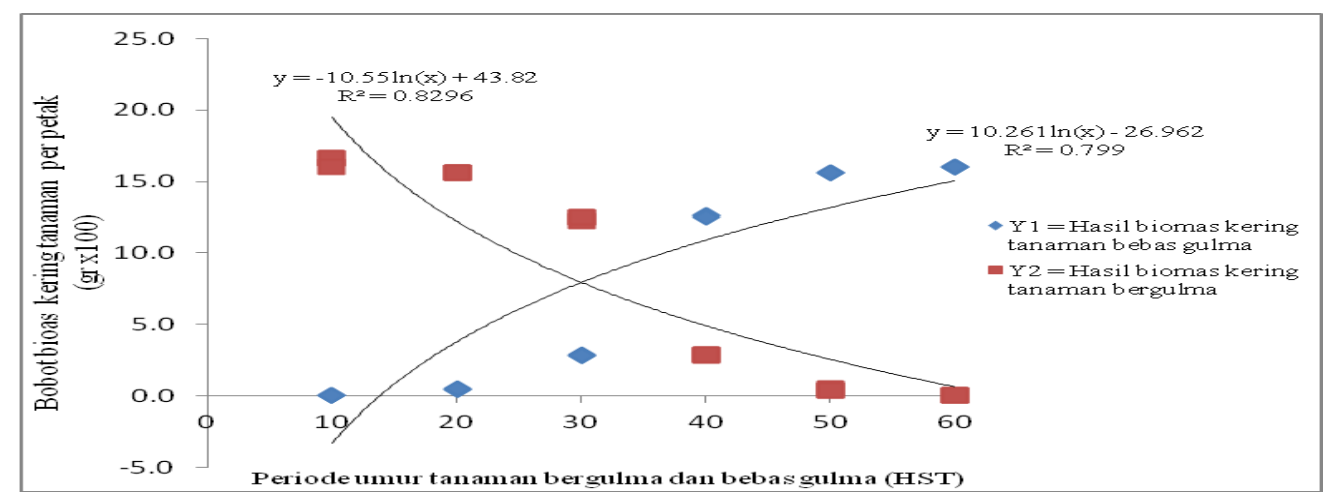

Gambar 2. Pengaruh periode umur tanaman bergulma dan bebas gulma terhadap kenaikan dan penurunan bobot biomas kering petak ${ }^{-1}$.

Berdasarkan hasil analisis regresi korelasi pengaruh periode tanaman bergulma dan bebas gulma terhadap kedua variabel tersebut maka dapat dinyatakan bahwa keberadaan gulma yang dapat ditoleirir pada tanaman jagung manis hanya sampai umur 30 HST. Gulma harus disiangi setelah tanaman berumur antara 30-40 HST. Bila penyiangan gulma dilakukan setelah tanaman berumur 40 HST, maka hasil tanaman tidak dapat diselamatkan. Jadi dapat dinyatakan bahwa periode kritis tanaman jagung manis yang ditanam pada entisol Lombok Tengah, yaitu pada periode umur 30-40 HST. Wilter Januardi Padang et al. (2003), melaporkan bahwa periode kritis tanaman jagung manis berkompotisi dengan gulma berlangsung antara umur 21-28 hari. Hasil penelitian Purwanti et al. (2012), menunjukkan bahwa keberadaan gulma akan menurunkan kualitas pertumbuhan dan hasil tanaman kedelai hitam pada umur 6 minggu setelah tanam. Periode kritis persaingan gulma pada pertanaman kedelai hitam terjadi 4-6 minggu setelah tanam. Singkatnya periode kritis tanaman jagung manis yang ditanam pada entisol Lombok Selatan diduga erat kaitannya dengan keberadaan jenis gulma yang tumbuh pada setiap perlakuan. Pada setiap petak perlakuan ternyata gulma Cyperus rotundus dan Cynodon dactilon yang paling dominan. Dominannya kedua jenis gulma tersebut karena memiliki ruang penyebaran yang luas, agresif dan sulit dikendalikan sehingga dampaknya sangat merugikan bila dibiarkan berada di sekitar tanaman. Kedua jenis gulma tersebut termasuk golongan gulma ganas. Species ini menggunakan jalur metabolisme primer C4, yang berarti mampu tumbuh baik pada kondisi cekaman kekeringan, panas dan cahaya rendah seperti di bawah kanopi tanaman (Nurlaili, 2010). Khusus untuk teki, kapasitas regeneratif dan penyebaran umbi-umbinya juga sangat berkontribusi untuk keuntungan kompetitif. Organ tumbuhan teki yang tumbuh dari satu umbi mampu menghasilkan lebih dari 100 umbi dalam waktu sekitar 100 hari (Rahnavard et al., 2000). Umbi teki mampu bertahan dorman lebih dari 5 tahun dan bila kelembaban terjaga akan tumbuh normal. Hal ini menyebabkan gulma teki mendapat julukan gulma terburuk didunia (Blum et al., 2000). Namun demikian kedua jenis gulma tersebut dapat dikendalikan dengan penyiangan manual yang tepat. Hal ini dapat dilihat dari hasil pengamatan bobot kering gulma pada saat tanaman berumur 60 hari bahwa, nilai bobot biomas kering gulma mengelami penurunan yang signifikan setelah perlakuan penyiangan atau tanaman mengalami periode bebas gulma pada periode waktu tertentu. 


\section{KESIMPULAN}

Periode kritis jagung manis berkompetisi dengan gulma pada entisol Lombok Tengan berada pada kisaran umur 30-40 hari setelah tanam. Keberadaan gulma yang dapat ditoleirir pada tanaman jagung manis hanya sampai umur 30 hari setelah tanam. Gulma pada jagung manis harus disiangi setelah tanaman berumur 30-40 hari setelah tanam. Bila penyiangan gulma dilakukan setelah tanaman berumur 40 hari, maka hasil tanaman tidak dapat diselamatkan. Tanaman yang berkompetisi dengan gulma selama 40, 50, dan 60 hari setelah tanam mengalami penurunan hasil sebesar 60,32 \%, 82,84\% dan 98,66\%. Sedangkan tanaman yang bebas gulma hanya selama 10, 20 dan 30 hari mengalami penuruan hasil sebanyak $98,61 \%, 80,16 \%$ dan $61,40 \%$.

\section{Ucapan Terima Kasih}

Terimakasih disampaikan kepada Bapak Rektor dan Ketua LPPM Universitas Mataram yang telah mendanai dan memberikan fasilitas program penelitian PNBP_ Peningkatan Kapasitas tahun anggaran 2020. Terimakasih kepada rekan-rekan angota tim penelitian yang telah membantu kegiatan penelitian ini dengan penuh ketekunan dan kesabaran.

\section{DAFTAR REFERENSI}

Bates, T.R., and J.P. Lynch. 2001. Root Hairs Confer a Competitive Advantage Under Low Phosphorus Availability. Plant and Soil 236: 243-250.

BPS, 2019. Statistik Tanaman Pangan di Indonesia (Khusus Tanaman Pangan Pokok). Badan Pusat Statistik Indonesia. Jakarta.

Blum, R.R., J. III. Isgris \& F.H. Yelfetron. 2000. Purple (Cyperus rotondus) and Yellow Nutsedge ( $C$. esculentus) Control in Bermuda grass (Cynodon dactylon). Journal Weed Technology. 14 (2): 357-365.

Ega, A.S., Husni Thamrin Sebayang \& Agung Nugroho. 2018. Pengaruh Waktu Penyiangan padaTumpang Sari Jagung (Zea mays L.) dan Kacang Tanah (Arachis hypogeae L.). Jurnal Produksi Tanaman 6 (9): 2085-2093.

Galon, L. \& Agostinetto, D. 2009. Comparison of empirical modelsfor predicting yield loss of irrigated rice (Oryza sativa) mixedwith Echinochloa spp. Crop Prot 28:825-830.

Gibson, K.D., Fischer, A.J., Foin, T.C. \& Hill, J.E. 2002. Implications of delayed Echinochloa spp. germination and duration of competition for integrated weed management in waterseeded rice. Weed Res. 42:351-358.

Kniss, A.R., Vassios, J.D., Nissen, S.J. \& Ritz, C. 2011. Nonlinear Regression Analysis of Herbicide Absorption Studies. Weed Sci. 59: 601-610.

Nedim, M., Acybn Unay, Ozhan Boz, \& Filiz Albay. 2004. Determination of Optimum Weed Timing in Maeze (Zea mays L.). Journal Agriculture. 28: 340-354.

Ngawit, I Ketut. 2008. Efek Periode Bebas Gulma dan Kerapatan Populasi Tanaman terhadap Daya Kompetisa Tanaman Jgung pada Asosiasi dengan Gulma. Crop Agro, Jurnal Ilmiah Budidaya Pertanian, Volume I (1): 53-59.

Nurlaili. 2010. Respon Pertumbuhan Tanaman Jagung (Zea mays L.) dan Gulma terhadap Berbagai Jarak Tanam. Jurnal Agronobios 2 (4): 19-29.

Purwanti, S. Ghaisani, \& Nasrullah. 2012. Penentuan Periode Kritis Cekaman Gulma Pada Kedelai Hitam (Glycine max (L.) Merill). Seminar Nasional Hasil Penelitian Fakultas Pertanian UGM. 11 September 2012. 
Rahnavard, A., Z.Y. Ashrafi, A. Rahbari \& S. Sadeghi. 2010. Effect of Diffrent Herbicedes on Control of Purple Nutsedge (Cyperus rotondus L.). Journal Weed Science. 16 (1): 57-66.

Setiawan, D.P., A.S. Karyawati \& H.T. Sebayang. 2014. Pengaruh Pengendalian Gulma pada Tumpangsari Ubi Kayu (Manihot Esculenta L.) dengan Kacang Tanah (Arachis hypogeae L.). Jurnal Produksi Tanaman 2 (3): 239-246.

Wilter, J.P., Edison Purba \& Eva Sartini Bayu, 2017. Periode Kritis Pengendalian Gulma pada Jagung (Zea mays L.). Jurnal Agroekoteknologi FP USU 5 (2): 409-414.

Zimdahl, R.L. 1980. Weed Crop Competion, a Review. Int. Plant Protection Centre. OregonState Univ. Corvalis. USA. 